\title{
МИСТЕЦТВОЗНАВСТВО
}

\author{
DOI: https://doi.org/10.32839/2304-5809/2021-9-97-12 \\ УДК 378:001.891]:78
}

Калашник М.П.

Харківський національний педагогічний університет імені Г. С. Сковороди

Мельніков С.B.

Дніпропетровська академія музики імені М. Глінки

\section{САКРАЛЬНА ТРАДИЦІЯ В СУЧАСНІЙ УКРАЇНСЬКІЙ БАЯННІЙ МУЗИЦІ}

\begin{abstract}
Анотація. У статті сучасна українська баянна музика позиціонована як концептуалізований перетин традищій та новацій, позначений розширенням стильової, жанрової, виразової палітри, креативною дуалістичністю й актуалізаціею сакральної традиції. Як чинники її розвитку в сучасній національній баянній музиці визначені: академічний статус баяну, осмислення його як інструмента з безмежним потенціалом; органологічна специфіка інструмента; полілогічність культури межі XX-XXI ст., відродження релігійного світобачення та проблематизація духовних пошуків людини. Виявлено такі варіанти інтерпретації сакральної традиції в сучасній українській баянній музиці: декларативне посилання на її канонічні жанрові витоки, закріплене на вербальному рівні (у творах В. Рунчака); звернення до закріплених у сакральному музичному мистецтві образів-символів, семантем (у творах В. Зубицького); символічна втілення на рівні знаків культурної пам'яті (у творах К. Цепколенко). Виявлено загальні тенденції сучасних національних баянних версій сакральної традиції: концептуальна та жанрово-стильова індивідуалізащія атрибутивних жанрових моделей; створення полілогу культур у діахронії та синхронії, зокрема у конфесійному вимірі; насичення знаками й алюзіями різних культур; новаційність музичного мислення та мови; експериментальна синтетичність, обумовлена новаційністю виконавських складів, значущістю візуального та вербального компонентів, театралізації та мультимедійності.
\end{abstract}

Ключові слова: баянне мистецтво, традиції, новації, стиль, жанр, культурна пам'ять.

Kalashnyk Mariya

H.S. Skovoroda Kharkiv National Pedagogical University

Melnikov Semen

Dnipropetrovsk Academy of music named after M. Glinka

\section{SACRED TRADITION IN MODERN BAYAN MUSIC}

Summary. Contemporary Ukrainian bayan art is a conceptualized sphere in which the academic instrument appears as a carrier of tradition and innovation, a mediator between cultures in synchrony and diachrony, focused in particular on innovation approbation of conceptually meaningful, genre-style, expressive horizons of experience enshrined in context. The active process of mastering this experience is due to following factors: consolidation of the academic status of the accordion in music practice as an instrument with unlimited potential; organological specificity of the instrument, which resonated with the timbre image of the organ, polyphonic thinking and the counterpoint technique, the focus of pluralistic postmodern culture on the dynamization of intercultural dialogue, the revival of religious worldview and problematization of personal spiritual pursuits. In contemporary bayan art the panorama 's components of interpretation of the sacred tradition are: a declarative reference to its canonical genre, fixed at the verbal level («Kyrie Eleison», "Passion for Vladislav», Sonata 1 "Passione» by V. Runchak); appeal to the images-symbol, semantics fixed in the context of sacred art ("Ave Maris Stella», "August Pieta» by V. Larchikov, "Lacrimosa», Sonata "Fatum» by V. Zubitsky); symbolic interpretation of the sacred tradition at the level of sings of cultural memory («Peoples are broken by exhaustion ... Cemetery music», «The one who comes out of the circle» by K. Tsepkolenko). General tendencies of interpretation of sacred tradition in bayan music of modern Ukrainian composers are: conceptual and genre-style individualization of attributive genre models; creation of a polylogue of cultures in diachrony and synchrony, in particular in the confessional dimensions; symbolizations of artistic space. Due to its saturation with things and allusions to the sings of different cultures; innovation of musical thinking and language; experimental syntheticity due to the novelty of the performances, the importance of visual and verbal components, dramatization and multimedia.

Keywords: bayan art, traditions, innovations, style, genre, cultural memory.

$\Pi$ остановка проблеми. Художня панорама межі сучасності являе собою пошукове поле, в якому суперечливо та неоднозначно співвідносяться традиції та новації, усталені сфери інструментального виконавства піддаються функціональній і семантичній модифікації. Одним із зразків такого модифікування протягом XX ст. із простору народної у простір академічної, масової музики, зокрема джазу, є баянне мистецтво. Набуття ним самостійного концерт- ного, мультифрунціонального статусу медіатора між просторами музичного мистецтва обумовлює «концептуалізацію народно-інструментальної поетики музикування» [5, с. 384], нерозривно пов’язану із потужною тенденцією розширення жанрової та виразової палітри.

У сучасній українській баянні музиці додаткового концептуального, жанрового, виразового, семантичного виміру цим спрямуванням надають інтеріоризована спрямованість митців на 
збереження національних витоків, фольклорного начала, їх проекції у сфреру новаційного музичного мислення й мови та тенденція формування нового образу виконавця. Атрибутивною для українського баянного мистецтва межі $\mathrm{XX}-\mathrm{XXI}$ ст. стае й «креативна дуалістичність»синтез композиторської та виконавської діяльності як основа для мобільного насичення простору сучасної національної баянної музики жанровими, стильовими, змістовно-семантичними, виразовими новаціями акцентами на рівні виконавської діяльності. Рефрлексивно-концептуальним виміром креативної дуалістичності стає для сучасного баянного мистецтва також спрямованість на опанування сакральної традиції в їі концептуально-образному та жанровому вимірах та в її новаційній трансформації.

Аналіз останніх досліджень i публікацій. Музикологічний вимір сучасного національного баянного мистецтва $е$ плюралістичною сферою, комплементарну цілісність якої забезпечують такі дослідницькі вектори: френоменологічний (I. Єргіев, С. Нефедов, А. Черноіваненко), історичний (М. Давидов, А. Душний, Є. Іванов, М. Імханицький, Б. Піц, Л. Понікарова, А. Сташевський), регіональний (М. Давидов, А. Душний, В. Свдокимов, А. Семешко, В. Шафета), стильовий (М. Булда, А. Душний, Ю. Дякунчак, Л. Пасічняк, Ю. Радко, А. Сподаренко), жанровий (А. Нижник, Я. Олексів, А. Сташевський), персоналістичний (А. Душний, I. Єргієв, I. Коновалова, А. Сташевський), теоретично-методичний (В. Власов, В. Дорохін, А. Душний, В. Князев, В. Салій, А. Семешко) тощо.

Невирішеними раніше частинами загальної проблеми е дослідження сакрального концептуально-змістовного вектору, сучасного українського баянного мистецтва. Його значущість і різноманіття втілень у жанрово-стильових параметрах національного баянізму водночас із відсутністю вичерпного висвітлення українською музикологіею обумовлюють актуальність статті.

Формулювання цілей статті. Метою розвідки є окреслення чинників актуалізації сакральної традиції та тенденцій іiі репрезентації у сучасній українській музиці для баяна.

Виклад основного матеріалу. Сягаючи своїми витоками сфери народно-інструментального музикування, баянне мистецтво з кінця XIX ст. перебувае в у процесі інтенсивної академізації. Концептуальними, жанровими та виразовими маркерами такої функціональної модуляції стае апробація у сфері баянного виконавства не тільки жанрів симфонії, сонати та концерту - усталених в академічній художній практиці у статусі носіїв філософського сенсу, концентрованих, «змістовно» згорнених символів кардинальних проблем людського буття. Інший вимір академізащії баянного мистецтва був пов'язаний із обробкамипроекціями на його технічно-виразову специфіку зразків світового музичного доробку епохи бароко та класищизму тощо. Своєрідним перетином тенденцій збереження первинного «образу» інструмента та його новаційного трансформування 3 поч. XX ст. явилася спрямованість митців на насичення репертуарних обріїв баянного мистецтва обробками фольклорної спадщини.
Потужним імпульсом щодо розширення простору буття національного баянного мистецтва та водночас модифікування означених тенденцій і торування нових шляхів утвердження баяну в системі художньої культури е апробація семантем і жанрових моделей сакрального музичного мистецтва. Чинниками ціеї тенденщії слід визнати не тільки творчу спрямованість митців на позищіонування баяна як інструмента 3 фактично безмежним технічним, тембровим, образним і виразовим потенціалом. Витоки актуалізації сакральної традицій в баянному мистецтві обумовлені й органологічною специфікою баяна, на рівні тембру суголосного органу, на рівні техніки - поліфронічному мисленню та контрапунктичній техніщі.

Сакральний «струмінь» сучасного національного баянізму мае імпульсами формування та розвитку загальні парадигмальні зрушення, детерміновану на світоглядному рівні потребу епохи постсучасності в перегляді системи ціннісних оріентацій, інтенсифікації пошуку духовних опор Людини-Митця та відродженні релігійних цінностей. Водночас значимим чинником розвитку цього спрямування стае тяжіння українських митців до відродження національних засад мистецького світобачення, нерозривно пов'язаних із релігійними основами, а також іманентно особистісна сутність їх осмислення. Це резонуе як із актуалізаціею особистісного начала в контексті виконавського мистецтва, так і діахронною та синхронною полілогічністю сучасної картини світу.

У зв'язку з динамізаціею міжкультурного діалогу, який зокрема детермінуе вихід нащіонального баянного мистецтва на світовий рівень, дослідники відзначають, що «формуючи поле притягнення-відштовхування концептів культу в історико-культурному та національному вимірах, міжкультурна комунікація в контексті тенденцій глобалізації та глокалізації концентровано відображае «напружену пульсацію» аксіологічних пошуків особистості» [6, с. 272]. Мистецькою проєкцією цих пошуків стає в сучасному національному баянному мистецтві сакральна традиція. У різнобарвній панорамі ї̈ особистісних інтерпретацій видається можливим окреслити декілька провідних спрямувань.

Один із них - безпосередне, деклароване на рівні авторської вербальної програми, посилання на сакральну традицію в її канонічних жанрових витоках, осмислену в координатах особистісного світобачення. Зразок такої інтерпретації - «Кугіе Eleison» (для скрипки і баяна, з текстами духовного концерту «Не отвержи мене у старості» M. Березовського) В. Рунчака. I. Коновалова у зв'язку зі специфікою втілення сакральної тематики у творчості композитора зазначае, що «сакральна сфера у творчості В. Рунчака характеризуеться індивідуальним підходом до тлумачення одвічних істин і набуває значення об'єкта рефлексії. Апелюючи до різних християнських традицій (католицької, англіканської, православної), автор трактуе релігійні образи як етико-фрілософрську лірику, позначену суб'єктивноособистісними переживаннями» [3, с. 55].

Твір е художнім парадоксом перш за все внаслідок накладання «пам'яті» жанру на світоглядні настанови постмодернізму. Вираженням такого суміщення $е$ іманентна, закладена внаслідок 
існування твору в різних версіях виконавського складу, варіативність твору - він був написаний у 1990 р. для фрортепіано, струнного квартету, фрлейти та кларнету (акцентуемо експериментальність виконавського складу), варіант для скрипки та баяна був створений 1992 р.

I3 постмодерністським осягненням культури як цілісного феномену, тяжінням до вільного, позбавленого часових і просторих кордонів, буття Людини в Культурі співвідноситься універсальний характер музичної мови. Митець, на програмному, вербальному рівні відсилаючи до католицької музичної традиції, уникає прямого звернення до їі знаків, фрормуючи своєрідний позаконфесійний простір духовних пошуків. Водночас репрезентація композитором спадку сакральної традиції як цілісності у часі та просторі детермінуе накладання у творі різних історико-культурних епох, виявлених зокрема й через опосередковане, алюзійне, quasi втілення їх музичних знаків. Такими знаковими «відблисками» на різнях рівнях музичної тканини твору є:

- тритонова інтонема (у партії скрипки), семантично визначена у контексті Середньовіччя;

- риторичні фрігури хреста (алюзійно відтворена), кружіння (circulatio) та питання (interrogatio), які резонують із бароковим музичним простором;

- примхливість ритміки, що співвідноситься зі специфрікою поліфонічного мислення епохи Ars Nova, та її змістотворна фрункція, що резонує із процесом емансипації ритму в музичній культурі початку Новітнього часу;

- псалмодичні інтонації та алюзї хорового звучання - атрибутивні знаки сакральної вокальної традищї, які перебувають у бароковому контрастному співставленні 3 хроматизованим мелосом інструментального характеру як «посиланням» на сучасну специфіку музичної мови;

- поліфонічне мислення та сонорика - як музично-мисленневі відповідники музичних культур Середньовіччя та Новітнього часу;

- різні архітектонічно-конструктивні принципи як знаки алгоритмів «упорядкування», логіки музичного мислення різних епох: рондо, як одна з найдавніших форм, сонатність (закладена на рівні алюзії у співставленні провідних інтонаційних ліній, пов'язаних із алюзією теми хреста та гранично хроматизованими інтонемами в 12-тоновій техніці), як знак раціонального класицистичного мислення та «вільна" форма, імпровізаційність якої співвідноситься із специфікою музичного мислення межі XX-XXI ст.;

- темперованість та нетемперованість звучання (у партії скрипки) - як співставлення різних векторів осмислення сутності музичного звуку;

- комплекс новітніх засобів виразності - гра смичком поза торкання струн, змістотворний та драматургічний статус пауз, спів / свист виконавців.

Світоглядна опора на жанрові архетипи сакральної традиції $е$ основою концепцї Сонати № 1 «Passione» та «Страстей за Владиславом» В. Рунчака. «Ореол» пассіонів у Сонаті № $1 \in$ результатом знакового «прочитання» спадку духовної культури, діалогізуванням творця 3 ним. Це виявляеться у насиченні музичної тканини твору бароковими риторичними фрігурами (мотив хреста, catabasis, anabasis, circulatio), застосуванні лейтмотивної техніки (як одного зі знаків романтичного музичного мислення), типовими для нововіденської школи 12-тонових інтонаційних побудов, сонорними ефектами, кластерами.

На рівні форми діалогізування зі спадком культури на грунті актуалізації сакральної традиції виявляеться у декларації сонатності як жанрової опори твору та їі романтично індивідуалізованої, «стисненої» до 1-частинності модифікації. На рівні засобів виразності діалогічна інтерпретація сакральної традиції в Сонаті № 1 «Passione» як імпульсу до позачасової та позапросторової особистісної редрлексії знаходить вираження у двоїстій музично-візуальній природі твору.

У такому статусі рушія рефлективної, самоідентифікаційної, інтровертно спрямованої діяльності, створення полілогу культур на всіх рівнях музичної тканини, драматургічного імпульсу розгортання дії «інструментального театру» постає сакральна традиція в жанрі Passion у «Страстях за Владиславом». А. Сташевський зазначає, що «в полістилістиці «Страстей» переплавлено кілька музично-стильових пластів 3 різними, навіть протилежними за культурною парадигмою моделями, які формують єдиний синтетичний музичний простір, a їх сукупний художній арсенал пронизаний єдиною лінією інтонаційно-драматургійного розвитку. Стильова різнорідність структурних елементів монументальної тектоніки симфонії трансформуеться в органічне ціле» [8, с. 250]. Саме звернення до духовності, до вічно актуальних для людини проблем стає тією концептуальною основою, на якій поєднані різнорідні стильові пласти.

Своєрідною апеляцією до сакральної традиції є звернення до закріплених у контексті сакрального музичного мистецтва згорнених образівсимволів, семантем. Такими є "Ave Maris Stella» та «Серпнева П'єта» В. Ларчікова. Створюючи міжконфесійний діалог, репрезентуючи осмислення сакральної традиції як цілісності, композитор звертається до католицької традищії - гімну «Ave Maris Stella» iз канонічним текстом, якій завдяки темброобразам баяна та скрипки постає як концентроване втілення духовності. I якщо за скрипкою такий темброво-семантичний вимір був закріплений у художній практиці, то уведення баяну в семантичну площину католищької музичної традиції засвідчує закріплення баяна в статусі медіатора між епохами та культурами, його потенціал щодо функціонування в різноманітних за своїми семантико-виражальними параметрами просторах. Проєкція католицького вокального літургічного гімну в темброво-семантичну площину і слугує "відкриттю» для баяна раніше неопанованого семіотичного простору та навпаки, відкриттю для цього простору баяна як його семантично суголосного тембрового втілення.

«Серпнева П'єта» для баяна, фрортепіано та 2-х віолончелей В. Ларчікова є одним зі зразків особистісного «розкодування» усталеної семантеми, позначеного їі модулюванням при збереженні семантичного потенціалу в реалії сучасності та в семантично відмінні простори: академічного мистецтва, репрезентованого фортепіано та віолончелями, та первинно народного - баян. 
Додаткові семантичні нюанси у втіленні стражденного образу як апокаліптичного прогнозу для всього людства «закладені» у «Серпневій П'єті» на вербальному рівні. Назви частин - «Нерухомий крик чайки над зруйнованим мостом на атолі Бікіні» та «Натюрморт з ядерним розп'яттям після дезінтеграції постійності пам'яті (Miserere Domini) - унаслідок апеляції до художнього - візуального досвіду та досвіду, накопиченого людством у науковій царині - надають творові мультитекстуальності та формують нові шляхи реалізації семантичного, тематично-образного та виражального потенціалу баяна.

Сакральна традиція у творчості В. Зубицького постае у варіативності утілень. Це і суто інструментальні її репрезентації на основі архетипових сакральних семантем ("Lacrymosa» для двох баянів, фрлейти та віолончелі), і твори синтетичної природи, в яких поєднані вербальне та музичне начала при домінантності останнього («Соната «Фатум» із читанням молитви «Отче наш»).

Із осмисленням культури як єдиного, хронотопічно цілісного феномену співвідноситься такий вимір інтерпретації сакральної традиції як відтворення іï на символічному рівні у знаках культурної пам'яті. «Знесиллям зламлені народи...Цвинтарна музика» К. Цепколенко - один із найбільш своерідних зразків трансформації релігійної традиції в сучасному культурному просторі, позначений апелюванням до її первинних концептів і кардинальною новаційністю на всіх рівнях музичного твору. Створений для баяна та відео-ряду, твір є унікальною інтерпретаціею жанру реквіему та меморіальної традиції як культурних кодів, концентратів духовної пам'яті та духовного досвіду.

Водночас композиторкою створена інтерпретація концептуальних основ жанру реквіему на грунті радикальної зміни його музично-виразових маркерів: первинно колективний, вокально-інструментальний жанр постае в сольному інструментальному варіанті, належність до національно нейтрального сакрального простору замінюеться змістовною акцентуаціею національного начала (твір присвячено пам'яті усіх народів, які зазнали геноциду), безумовна домінанта музичного начала - синкретичним еднанням музичного та візуального начал (наявність світло- та відео-ряду - фотографій цвинтарів часів Австро-Угорської імперії), мультимедійністю.

Деструкція атрибутивних рис жанру у творі співвідноситься із провідними тенденщіями сучасного жанротворення в українській музиці, у зв'язку з особливостями якого С. Кравченко декларуе значущість принципу «перерозподілу балансу стабільних і релятивних компонентів жанрової структури» [4, с. 200]. Для К. Цепколенко у «Цвинтарній музиці» стабільним компонентом стає саме концептуальна основа жанру, його dpiлософська природа та зверненість до кардинальних проблем людського буття.

Маркером інтерпретації сакральної традиції у творі стає максимальна концентрація ії семантики - змістотворна концептуалізація інтонеми lamento, позначеної граничною об’емністю історико-культурної пам'яті як символу особистісної та загальнолюдської скорботи. Семантичною значущістю у творі позначені також «серія cantabile магічного, таемничого характеру; мікроформула септим для вираження всеохопного страху та моторошності (людина на цвинтарі вночі); репетиції- відображення напруги атмосфери звукового простору; ритм перкусії - пульс людського жаху; віртуозні пасажі та шумові ефекти перкусії - шелест листя на цвинтарі» [1, с. 181].

Своерідної культурної «об’емності» цій знакові панорамі надае резонування із антиномічною бароковою естетикою. Ії домінантне значення обумовлене дією принципу контрасту на всіх рівнях організації твору, Контраст виявляеться у співставленні: власне музичного та візуального начал; інтонаційно організованого (баян) та інтонаційно нейтрального (перкусія) начал; ритмізованої стадіальності (ритмічна етапність розгортання відеоряду) та перманентної процесуальності (наскрізний розвиток тематизму у партії баяна); інтонем - носіїв концентрованого змісту, закріпленого на рівні перцепції та експериментальних звукообразів (шуми перкусії, вербалізація партії баяніста -імітація ним дзижчання як символу цвинтарних скрипів тощо).

На концептуальному рівні співвідноситься із сакральною традиціею твір для баяна-соло К. Цепколенко «Той, що виходить із кола». Твір $\varepsilon$ показовим як утілення іншого виміру тенденції «креативної дуалістичності» - формування творчої співдружності композитора та виконавця. Закріплена у такий спосіб двоїстість (К. Цепколенко - I. Єргієв) обумовлюеться, на думку I. Єргієва, «збігом естетичних установок композитора і виконавця з їх яскраво вираженим прагненням до нової духовності, які реалізують свое творче кредо під гаслом «Про вічне - новою музичною мовою!» [2, с. 203-204].

Спрямованість на порушення вічних проблем і е тіею ниттю зв'язку, яка поєднуе в цілісність духовний спадок сакральної музичної традиції та новаційність музичного мислення, жанрової організації та мови, спектру засобів виразності. Знаком «дотичності» до сакрального начала, віддзеркаленого у творі світоглядному рівні, є змістотворна значимість інтровертності. Хоронотоп медитативної зосередженості на композиційно-структурному, інтонаційному, тембровому рівнях виявляеться у таких характерних рисах твору, як: статичність, уникання процесуальності, виражене в тривалості педалей; алюзійна «органна» темброва барва; надання лейт-інтонемі м. 3 статусу змістотворного символу; алюзійне відтворення риторичних фігур хреста, anabasis (в деяких випадках у суміщенні) та catabasis.

На рівні тембрики та сонорики новащійність інтерпретації сакральної традиції у творі К. Цепколенко «Той, що виходить із кола» відображаеться в застосуванні нетрадиційних засобів виразності. Беззвучне оперування міхом, стук по міх, глісандо по ладах кулаком, проте мають значення не тільки яскравої тембрової барви, а й слугують своєрідними «розділовими знаками» у контексті структури-композиції твору.

Висновки. $\mathrm{y}$ самостійному концертному статусі та статусі медіатора між просторами музичного мистецтва сучасне баянне мистецтво оріентовано на опанування новітніх концептуально-змістовних, жанрово-стильових, виразових обріїв, пов'язаних із сакральною традицією. 
Чинниками ii актуалізації у просторі українського баянного мистецтва є: закріплення академічного статусу баяну в музичній практиці як інструмента з безмежним потенціалом; органологічна специфіка інструмента, співвідносна із тембральним образом органа, поліфонічним мисленням, контрапунктичною технікою, спрямованість плюралістичної культури постсучасності на динамізацію міжкультурного діалогу, відродження релігійного світобачення та проблематизацію особистісних духовних пошуків людини.

У сучасному українському баянному мистецтві складовими панорами інтерпретації сакральної традиції є: декларативне посилання на їі канонічні жанрові витоки, закріплене на вербальному рівні («Kyrie Eleison» для скрипки та баяна, "Страсті за Владиславом», Соната № 1 «Passione» В. Рунчака); звернення до закріплених у контексті сакрального музичного мистецтва образів-символів, семантем (Аve Maris Stella», "Серпнева П’ета» В. Ларчікова, «Lacrymosa», Соната «Фатум» В. Зубицького); символічна інтерпретація сакральної традиціі на рівні знаків культурної пам’яті («Знесиллям зламлені народи... Цвинтарна музика», «Той, що виходить із кола» К. Цепколенко).

Загальними тенденціями інтерпретації сакральної традиції у баянній музиці сучасних українських композиторів $\epsilon$ : концептуальна та жанрово-стильова індивідуалізащія атрибутивних жанрових моделей; створення полілогу культур у діахронії та синхронії, зокрема у конфесеійному вимірі; символізація художнього простору, обумовлена його насиченням знаками й алюзіями знаків різних культур; новаційність музичного мислення та мови; експериментальна синтетичність, обумовлена новаційністю виконавських складів, значущістю візуального та вербального компонентів, театралізації та мультимедійності.

Значимість сакральної традиції як чинника творчих пошуків сучасних українських митців, динамічне розширення панорами ії утілень надає їй статусу перманентно оновлюваної сфери сучасного баянного мистецтва і спонукає до виявлення специфіки їі конкретних утілень у творчості В. Рунчака, О. Щетинського, В. Зубицького, К. Цепколенко тощо, що складає подальші перспективи дослідження.

\section{Список літератури:}

1. Єргіев І. Д. Акордеонна творчість композиторки Кармели Цепколенко. Музичне виконавство. Науковий вісник НМАУ іл. П. І. Чайковського. 2002. Вип. 8. Кн. 5. С. 173-184.

2. Єргієв I. Д. Артистичний універсум музиканта-інструменталіста кінця XX - початку XXI століття : дис. ... докт. мистецтвознавства : 17.00.03. Одеса : ОНМА, 2016. 454 с.

3. Коновалова І. Ю. Творчість В. Рунчака: сутність, контексти, суб’єктивно-особистісні проекції. Мистецтвознавчі записки. 2012. Вип. 28. С. 51-58.

4. Кравченко А. I. Семіологія камерно-інструментального мистецтва України кінця XX - початку XXI століть : дис. ... докт. мистецтвознавства : 26.00.01. Київ : НАКККіМ, 2021. 428 с.

5. Снедкова Л. Дует баяністів як різновид ансамблевого музикування в Слобожанщині. Проблели взаєлодії мистеитва, педагогіки та теорії і практики освіти. 2014. Вип. 41. С. 380-390.

6. Стасевская О. А., Уманец О. В. Историческая память как фрактор межкультурной коммуникации. Национальные культуры в межкультурной коллуникаиии : материалы V Междунар. науч.-практ. конф. (Минск, 31 марта - 1 апр. 2020). Минск, 2020. С. 270-278.

7. Сташевский А. Жанровые и формообразующие аспекты современной баянной музыки (на примере творчества украинских композиторов). Studia Pedagogiczne. Problemy Spoleczne, Edukacyine i Arttystyczne. 2014. № 23. C. 117-126.

8. Сташевский А. Полістилістичні тенденції в баянній музиці сучасних українських композиторів. $K y л ь т у р а ~$ України. 2012. Вип. 37. С. 247-255.

\section{References:}

1. Iergiiev I. D. (2002) Accordeonna tvorchist compozytorki Karmely Tsepkolenko [Accordion works by composer Carmela Tsepkolenko]. Musichme vykonavstvo. Naukoviy visnyk NMAU im. P. I. Tchaikovskogo, 8, 5, $173-184$. (in Ukrainian)

2. Iergiiev I. D. (2016) Artystychnyi universum musicanta-instrumentalista [Artistic universe of a musicianinstrumentalist], (Doctors thesis). Kyiv. (in Ukrainian)

3. Konovalova I. Yu. (2012) Tvorchist V. Runchaka: sutnist, konteksty, subyektyvno-osobystisni proyektsiyi [Creativity of V. Runchak: essence, context, subjective personal projection]. Mystetstvoznavchi zapysky, 28, 51-58. (in Ukrainian)

4. Kravchenko A. I. (2021). Semiologiya kamerno-instrumentalnogo mystetstva Ukrayiny kintzya XX - pochatku XXI stolit [Semiology of the instrumental chamber art of Ukraine of the late XX - early XXI centuries], (Doctors thesis). Kyiv. (in Ukrainian)

5. Snedkova L. A. (2014) Duet bayanistiv yak riznovyd ansamblevogo musycuvannya v Slobozhaszhiny [A bayan player duet as a Slobozhanszhina encemble musicianship variety]. Problemy vzayemodiyi mystetstva, pedagogiky ta teoriyi i practyky osvity, 41, 380-390. (in Ukrainian)

6. Stasevskya O. A., Umanets O. V. (2020) Istorycheskaya pamyat kak factoe mezhculturnoy communicatziyi [Historical memory as a factor of intercultural communication]. Proceedings of the Natsionalnyie cultury $v$ mezhculturniy communicatsiyi (Belorussiya, Minsk, March 31 - April 1, 2020). Minsk: BGU, pp. 270-278. (in Russian)

7. Stashevsky A. (2014). Zhanrovyie I formoobrazuyuszhiye aspect sovremennoy bayannoy musyki (na primere tvorchestva ukrayiskikh compositoriv [Genre and form-forming aspects of modern accordion music (on the example of the works of Ukrainian composers). Studia Pedagogiczne. Problemy Spoleczne, Edukacyine i Arttystyczn, 23, 117-26. (in Russian)

8. Stashevsky A. (2012) Polystylistychni tendentsiyi v bayanniy musitsi suchasnykh compositoriv [Polystilistic tendencies in accordion music of contemporary Ukrainian composers]. Cultura Ukrayiny, 37, 247-255. (in Ukrainian) 